\title{
COMPETITIVENESS OF MUTUAL AGRARIAN FOREIGN TRADE OF THE POST-SOVIET COUNTRIES
}

\author{
Irena Benešová', Luboš Smutka², Jana Hinke³, Adriana Laputková4
}

\footnotetext{
1 Czech University of Life Sciences, Faculty of Economics and Management, Department of Economics, Czech Republic, ORCID: 0000-0002-9381-063X, benesova@pef.czu.cz;

2 Czech University of Life Sciences, Faculty of Economics and Management, Department of Economics, Czech Republic, ORCID: 0000-0001-5385-1333, smutka@pef.czu.cz;

3 University of West Bohemia, Faculty of Economics, Department of Finance and Accounting, Czech Republic, ORCID: 0000-0001-6767-1253, hinke@kfu.zcu.cz;

4 Czech University of Life Sciences, Faculty of Economics and Management, Department of Languages, Czech Republic, ORCID: 0000-0001-6483-9081, laputkova@pef.czu.cz.
}

\begin{abstract}
The paper is an analysis of foreign trade of the post-Soviet countries conducted for years 2000 and 2015. The aims of the research were thus twofold: to examine the bilateral trade scheme for the selected countries and to attempt to explore relations between competitiveness and thus the position of the agricultural commodity aggregates. The UN COMTRADE database was used. In the monitored countries, there is continuous growth of the commodity aggregate 0 - Food and live animals, which is strongly influenced by the commodity sub-aggregates 02 - Dairy products and bird eggs, S3-04 - Cereals and cereal preparations. The first phase entailed calculations of individual indicators of mutual trade (RCA, LFI, GLI and coverage of import). Subsequently, the indicators were used as input variables for further analyses. Using RCA and LFI indexes, the commodity aggregates were classified into 4 quadrants according to their position within the comparative advantage and competitiveness.

Using a cluster analysis (based on Euclidian distance and Ward's method), individual commodity aggregates for the monitored countries were divided into groups based on the values of GLI, LFI and coverage of import. The groups were subsequently characterized for individual countries. Based on the conducted analyses, it can be stated that hypothesis 0 about the non-existence of significant changes within the group structure does not reflect the reality. Between 2000 and 2015, substantial changes occurred in terms of dividing the commodity aggregates into groups based on their common characteristics with regard to foreign trade.

In addition, the diversity within foreign trade decreased between 2000 and 2015, and more commodity aggregates attain values around or below the average of a given aggregate. When assessing the intraindustry trade, it can be stated that some commodity aggregates can be regarded as important only with regard to Azerbaijan, Russia, Belarus, Kazakhstan and Ukraine. In these countries, this phenomenon is most frequently evident in the commodity aggregates Beverages or Vegetables and fruit.
\end{abstract}

Keywords: Post-Soviet countries, cluster analysis, LFI, RCA, GLI, commodity group.

JEL Classification: F14, Q02.

APA Style Citation: Benešová, I., Smutka, L., Hinke, J., \& Laputková, A. (2020). Competitiveness of Mutual Agrarian Foreign Trade of the Post-Soviet Countries. E\&M Economics and Management, 23(3), 49-66. https://doi.org/10.15240/tul/001/2020-3-004

\section{Introduction}

Agrarian foreign trade represents an integral part of the majority of the world countries' foreign trade. Agriculture in the countries with a lower economic performance can represent potential for economic growth when excess 
workforce is employed in sectors with higher added value and surpluses are realized through foreign trade or, on the contrary, can also be restrictive. This case concerns the countries with an inadequate agricultural foundation or the so-called net food importing countries. Agricultural foreign trade can thus serve as a source as well as an obstacle to economic growth. It is also necessary to mention that agriculture also produces public property in the form of tackling hunger or combating poverty.

The post-Soviet republics represent a substantially heterogeneous group despite their common history. The group of selected post-Soviet countries (not those in EU) comprises Armenia (AR), Azerbaijan (AZ), Belarus (BE), Georgia (GE), Kazakhstan (KZ), Kyrgyzstan (KG), the Republic of Moldova (MO), the Russian Federation (RU), Tajikistan (TJ), Turkmenistan (TR), Ukraine (UA) and Uzbekistan (UZ). For some of these countries, agrarian foreign trade represents an important part of their overall foreign commerce. Due to the existence of certain regionalizing tendencies, the question arises whether, for instance, more trade is conducted within individual groupings or the structure of the trade is significantly different (Azizov, 2017). The post-Soviet republics also represent a different political structure - mostly autocratic regimes in which entire agreements on free trade or higher levels of integration do not reflect the strongest economic relations but rather mutual dependency (Libman \& Vinokurov, 2018; Portanskii, 2012). Both foreign trade and regional integration agreements also promote installation or consolidation of autocratic regimes in other countries (Obydenkova \& Libman, 2016).

Currently, more than a half (circa 55\%) of the global trade is conducted as a part of regional trade agreements. Although regional integration is frequently discussed in the world economy, it is not a new topic. In this regard, it is necessary to state that although there is relatively extensive literature which discusses the reasons leading to regional integration or the impact of integration groupings on the national or regional economy, very few authors discuss the political or social aspect of this issue. The benefits and assessment of regional cooperation have been addressed by (Cavoli, 2012; Commendatore, Kubin, Petraglia, \& Sushko, 2014; Espinoza, Prasad, \& Williams,
2011; Geldi, 2012; Guesmi \& Teulon, 2014; Ke, 2015; Kumar, Sen, \& Srivastava, 2014; Minniti \& Parello, 2011). When discussing economic integration, the term itself contains elimination of various barriers to trade. This concerns tariff and non-tariff measures which hinder free trade. In this regard, national borders also represent an obstacle to free trade and for this reason it is impossible to perceive the competition as perfect when considering regional integration groupings.

\section{Current State of Knowledge}

The problem of foreign trade in the majority of the post-Soviet republics lies in its structure with heavy dependence on primary commodities (Hare, Estrin, Lugachyov, \& Takla, 1998; Horváth \& Zeynalov, 2014). This mainly concerns natural raw materials which represent the basic source of economic growth (Bildirici \& Kayikçi, 2013; Cavalcanti, Mohaddes, \& Raissi, 2011; Havránek, Horváth, \& Zeynalov, 2016). However, this condition is unsustainable longterm.

Agriculture represents one the most protected areas of economic activity in every country. At the same time, international trade is important for a large number of agricultural products. Liberalization of the global trade provides sufficient market opportunities for individual commodities. However, it also represents a threat to the countries which do not possess a competitive advantage over their trading partners and might also lead to deterioration of the food security situation.

In the case of the post-Soviet republics, the situation is different both in agriculture and in agrarian foreign trade. Land reform still has not been undertaken in some of the countries and agricultural production is more or less controlled by the state (Benešová, Novotná, Šánová, \& Laputková, 2016b; Cormier, 2007; Lerman, 2009). Even though this concerns the countries which, despite their heterogeneity, possess the same legislative environment, their approach to liberalization of not only their agrarian foreign trade differs (Mazhikeyev \& Edwards, 2013; Mazhikeyev, Edwards, \& Rizov, 2015). It is also widely accepted in these countries that through regional cooperation and establishment of a supranational competition policy they can contribute to a greater degree to market liberalization (Libman, 2007). Nonetheless, inclusion of agrarian markets 
in economic liberalization or directly in free trade or customs union can be particularly problematic, not only because it includes a very sensitive and specific area of the national economy, but predominantly in socio-political terms (Rueda-Junquera, 1998). One of the factors that can contribute to agrarian market liberalization is one's membership in WTO which expects customs barriers to be reduced or removed (Portanskii, 2012). However, should the market liberalization occur, the competitiveness of agrarian commodities would have to be significantly strengthened. Nevertheless, this is extremely difficult in the case of linking the economy and politics, which is typical for hybrid regimes (Hale, 2010, 2011). Malle (2012) adds that regarding Russia, this concerns a symbiosis between the government and large industrial sectors at both local and central levels. However, an economy that is semi-closed or entirely closed to international competition does not have an opportunity to modernize and increase its international competitiveness.

Nevertheless, the structure of Russian export depends on the differences between domestic and world prices with very low competitiveness of, for example, food, agricultural and wood products (Benešová, Maitah, Smutka, Tomšík, \& Ishchukova, 2017). Gnidchenko and Salnikov (2013), Gnidchenko and Sal'nikov (2014) mention that Russia is competitive in regard to raw materials. (Salnikov, Gnidchenko, \& Galimov, 2016) also state that the mere reduction of import rates does not always result in an increase in the competition.

Currently, there are no studies focusing on the competitiveness of the mutual agrarian foreign market within the post-Soviet republics.

\subsection{Hypothesis Development}

Weber (2003) states that Russia represents the major exporter of agri-food products, whereas Kazakhstan is more export-oriented. Garanina (2009), Garanina and Pankki (2008) mention that agricultural raw materials in the structure of the Russian foreign trade declined during the monitored period. There are countries that export more agricultural products to Europe than to Russia and other post-Soviet countries (Chiaruttini, 2014). On the other hand, the Central Asian republics have significant trade relations with China and other Asian countries (Linn, 2012; Spechler \& Spechler, 2013; Yun \& Park, 2012).
The majority of the post-Soviet republics focus on producing similar commodities and only occasionally produce different goods. However, similar production does not enable diversification of the risks connected with growing individual types of crops. On the other hand, these crops are closely connected to food security and represent an essential dietary component. In the case of the common approach of the post-Soviet republics, a similar commodity structure can also influence international prices as it allows monopoly systems to be employed (Benešová, Novotná, Šánová, \& Laputková, 2016a). Other countries are crucial for many of the post-Soviet republics' agriculture owing to the necessity to utilize their infrastructure as well in order for them to be able to realize their products on the international market. This concerns for example Kazakhstan, Uzbekistan or Belarus which lack access to the sea, therefore they need to use other countries' facilities for maritime transport. Agricultural production of the postSoviet republics represents a significant proportion of global production. However, for this reason volatility could influence prices of agricultural produce, namely of food on the global market. The prices of food are continuously rising, although substantial fluctuation is evident with some commodities, which results in this segment's instability. Erokhin (2020) investigates competitiveness of mutual trade within central Asia with the focus on the agricultural value chain. However, no author discusses the complex issue of these countries' mutual trade after the dissolution of the Soviet Union. Due to the existing, although in some cases weaker, mutual interconnection it is necessary to examine these countries not only as geographical units (Caucasus, central Asia, eastern Europe), but also as a complex of countries.

The factors mentioned above negatively influence competitiveness of agricultural production of the monitored countries. However, it is not clear whether there is any change in competitiveness during the monitored period nor what the position of the individual monitored countries within the post-Soviet region is.

Based on the information obtained by the authors, there is currently no study that compares competitiveness of agrarian commodity aggregates of these countries. The assessment of competitiveness should be based on two 
complementary parts. One of these should involve evaluation of competitiveness of the monitored commodity aggregates across the monitored countries. The second should subsequently concern evaluation of competitiveness of the monitored countries regarding individual commodity aggregates. This complex approach will enable an analysis of the competitiveness of agrarian products in the monitored countries as well as the position of individual countries.

Based on the above facts, the research hypotheses related to the competitiveness of the monitored countries and their position in the mutual trade can be formulated:

HO: Competitiveness of the monitored countries in individual commodity aggregates is currently similar. This concerns commodities which do not represent key agrarian sector products.

H1: There are commodity aggregates which are key for individual countries whose competitiveness during the monitored period changed significantly.

\section{Aim and Methodology}

Foreign trade in agricultural commodities represents an important part of export of primary commodities. This paper explores agricultural trade between selected post-Soviet countries with respect to its contribution to the overall foreign trade and the trade pattern. It measures the impact of agricultural trade on the competition of the countries within the group. The main aim of the paper is to conduct an analysis of competitiveness of the post-Soviet countries' agrarian foreign trade with regard to the position of individual countries as well as the position of individual commodity aggregates. The purpose of the analysis is to assess the position and the development of individual commodity aggregates and monitored countries.

Therefore, the authors will attempt to answer the following questions:

1. How have the changes of agrarian foreign trade been manifested in the overall competitiveness of this sector of foreign trade in the monitored period of 2000-2015?

2. How have the potential changes of the competitiveness of the monitored commodity aggregates been manifested in the individual countries' position?

\subsection{Data Description}

The export and import data have been retrieved from the UN COMTRADE database. These refer to the period between 2000 and 2015. The data are based on the Standard International Trade Classification (SITC) Rev. 2 nomenclature. A mostly two-digit level of aggregation is used, consisting of the products mentioned in Tab. 1.

\begin{tabular}{|c|c|c|c|c|c|}
\hline $\begin{array}{l}\text { One } \\
\text { digit }\end{array}$ & $\begin{array}{l}\text { Two } \\
\text { digit }\end{array}$ & Description & $\begin{array}{l}\text { Two } \\
\text { digit }\end{array}$ & Description & One digit \\
\hline \multirow{8}{*}{ 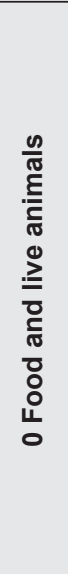 } & 00 & $\begin{array}{l}\text { Live animals other than } \\
\text { animals of division } 03\end{array}$ & 08 & Feeding stuff for animals & \multirow{2}{*}{$\begin{array}{c}0 \\
\text { Food and live } \\
\text { animals }\end{array}$} \\
\hline & 01 & Meat and meat preparations & 09 & $\begin{array}{l}\text { Miscellaneous edible products } \\
\text { and preparations }\end{array}$ & \\
\hline & 02 & Dairy products and bird eggs & 11 & Beverages & \multirow{2}{*}{$\begin{array}{c}1 \\
\text { Beverages } \\
\text { and tobacco }\end{array}$} \\
\hline & 03 & $\begin{array}{l}\text { Fish, crustaceans, molluscs } \\
\text { etc }\end{array}$ & 12 & $\begin{array}{l}\text { Tobacco and tobacco } \\
\text { manufactures }\end{array}$ & \\
\hline & 04 & $\begin{array}{l}\text { Cereals and cereal } \\
\text { preparations }\end{array}$ & 41 & Animal oils and fats & \multirow{3}{*}{$\begin{array}{c}4 \\
\text { Animal and } \\
\text { vegetable } \\
\text { oils, fats and } \\
\text { waxes }\end{array}$} \\
\hline & 05 & Vegetables and fruit & 42 & $\begin{array}{l}\text { Fixed vegetable fats and oils, } \\
\text { crude, refined or fractionated }\end{array}$ & \\
\hline & 06 & $\begin{array}{l}\text { Sugars, sugar preparations } \\
\text { and honey }\end{array}$ & 43 & $\begin{array}{l}\text { Animal or vegetable fats and } \\
\text { oils, etc }\end{array}$ & \\
\hline & 07 & \multicolumn{3}{|c|}{ Coffee, tea, cocoa, spices, and manufactures thereof } & \\
\hline
\end{tabular}


The initial analysis will be conducted at a one-digit level of aggregation. In this regard, only three commodity aggregates that include agricultural products will be analysed in more detail. This concerns group 0, 1 and 4 .

\subsection{Research Methods}

An analysis of competitiveness can be conducted from the lowest level (company) through industry competitiveness to the highest possible level, the state competitiveness. The objective of this research is to analyse comparative advantages at the state level and internationally, for comparison. There are different assessment indicators for this comparison which will be used to explore foreign trade of the monitored countries.

Firstly, a trade flow analysis will be conducted with the focus on the development of import, export, their composition and dynamics. Subsequently, competitiveness indexes will be calculated:

1. Balassa Index (BI) (Balassa, 1965, 1977) in order to determine specialization of export. An assessment of competitiveness $\mathrm{BI}$ will be conducted according to Laursen (2015). RCA > 1 - the country possesses a competitive advantage. RCA $<1-$ the country possesses a competitive disadvantage.

2. Gruber Lloyd Index (GLI) (Grubel \& Lloyd, 1971) to evaluate intra-industry trade in the overall trade. $\mathrm{GLI}=1$ - only intra-industry trade exists $\mathrm{GLI}=0$ - there is no intraindustry trade, only inter-industry trade.
3. Lafay Index (LFI) in order to assess mutual trade (lapadre, 2001; Lafay, 1992). It gains values $\langle-\infty, \infty\rangle$, if the value exceeding zero is gained, the country possesses a comparative advantage.

Lafay and Balassa indexes are used to divide the countries into four quadrants (Fig. 1). The best is number I, the countries located in it possess a general comparative advantage. On the other hand, quadrant number III consists of the countries without any competitiveness and comparative advantage (more about this problem Benešová, Smutka, \& Laputková, 2019). This analysis will be conducted for all the products and selected countries.

Individual calculations will subsequently be utilized as input variables for cluster analysis, using which individual countries and products will be classified. For the purposes of this research, hierarchical clustering will be used, based on Ward's method, in order to calculate the squared Euclidian distance (Ward, 1963). The values will be transformed using the z-score in order to prevent distortion resulting from different levels. Subsequently, individual categories will be characterized using average values of the utilized indicators. The final step will be to assess the differences between the categories. In this case, nonparametric tests will be used - relating samples of the Wilcoxon signed-rank test (Rosner, Glynn, \& Lee, 2006) to HO: the median of the differences between two groups equals 0 . The significance level is 0.05 .

Multidimensional scaling will be used and perceptual maps will be created for graphic illustration (Buja \& Swayne, 2002; Torgerson, 1952).

\section{Fig. 1: Division of the countries according to LFI and RCA}

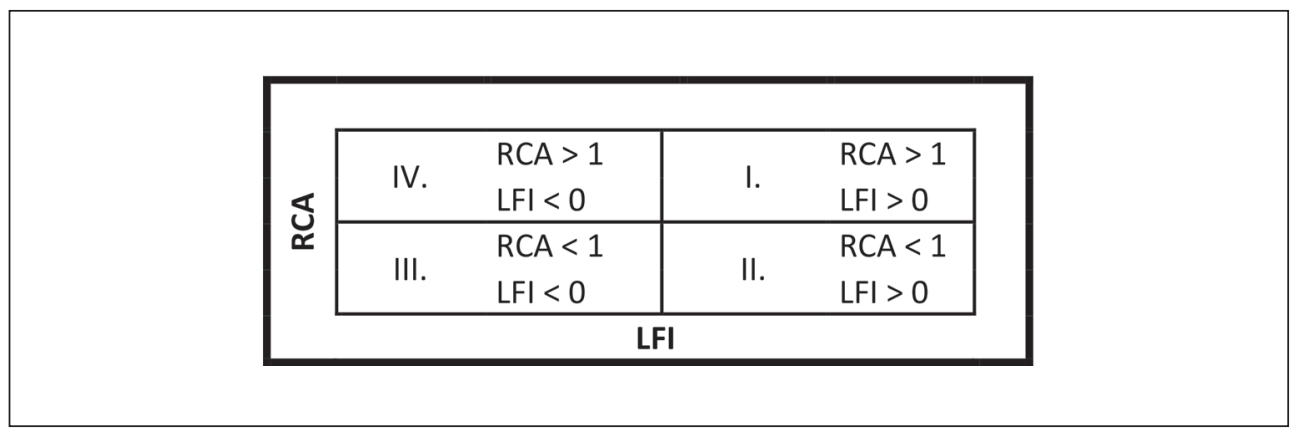




\section{Fig. 2: Development of proportion of monitored commodity aggregates (one-digit) to overall trade}

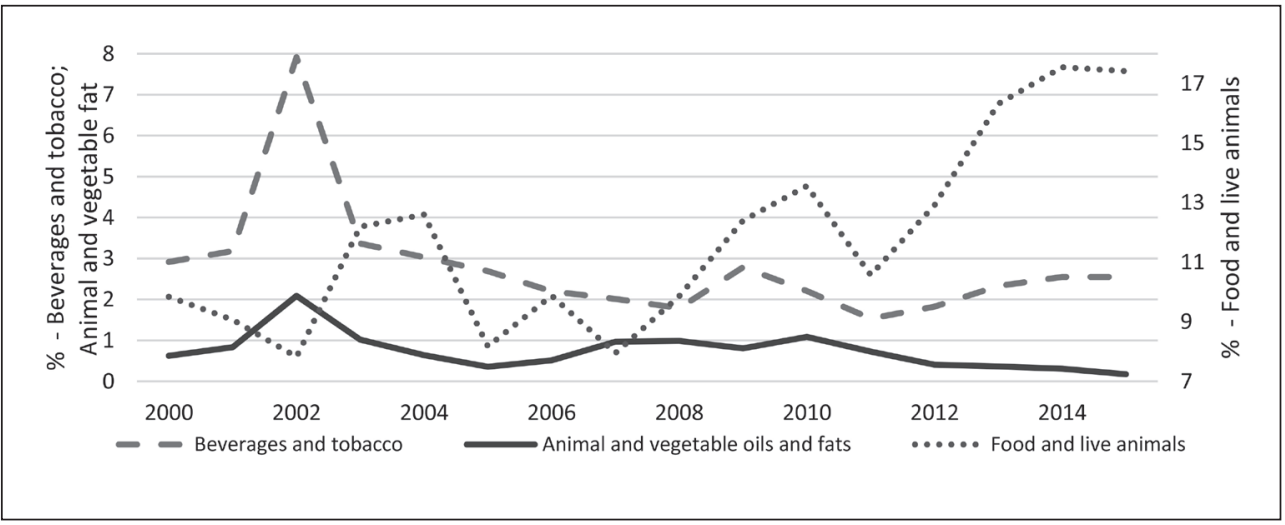

Source: own based on UN COMTRADE data

\section{Composition of the Post-Soviet Countries' Foreign Trade}

During the monitored period, the structure of foreign trade of the post-Soviet republics changed slightly. The proportion of agrarian commodities to overall foreign trade of the monitored countries has long-term amounted to approximately $15 \%$. (Fig. 2). However, there are significant differences between the monitored countries, for example, the proportion of Russia is considerably lower than that of Uzbekistan.

When assessing the development tendencies of agrarian foreign trade, it is evident that the commodity aggregate Food and live animals (one-digit code) records longterm growth in the post-Soviet republics in the last monitored period between 2011 and 2015 (Fig. 2). The products included in this commodity aggregate were traded in the monitored period within $\mathrm{CIS}$ between the majority of the countries.

A comparative advantage is one of the key indicators of overall competitiveness of a given country. The Russian Federation is one of the states with the largest proportion of comparative advantages in relation to the monitored countries. In 2000, Russia did not possess a comparative advantage in the commodity aggregate Food and Live animals (one digit) only in its trade with Belarus, Ukraine and Uzbekistan (Tab. 2). In 2015, this concerns Ukraine only.

In the case of Ukraine, the most noticeable decline in comparative advantages is evident. At the beginning of the monitored period, Ukraine possessed comparative advantages over all the countries except for Russia.

Regarding the analysis (Tab. 2) based on the higher level of classification (two-digit), the commodity aggregate Dairy products and bird eggs (02), Cereals and cereal preparations (04) and Beverages (11) record the highest values long-term. It is evident that between 2000 and 2015 the structure of export of the monitored countries changed.

Tab. 2: Composition of mutual export between post-Soviet countries $(2000,2015)$

\begin{tabular}{c|c|c|c|c|c|c|c|c|c|c|c|c|c|c} 
& S3-01 & S3-02 & S3-03 & S3-04 & S3-05 & S3-06 & S3-07 & S3-08 & S3-09 & S3-11 & S3-12 & S3-41 & S3-42 & S3-43 \\
\hline 2000 & $14.7 \%$ & $11.7 \%$ & $2.3 \%$ & $12.8 \%$ & $7.8 \%$ & $13.8 \%$ & $6.9 \%$ & $0.7 \%$ & $2.6 \%$ & $12.0 \%$ & $8.8 \%$ & $0.1 \%$ & $5.5 \%$ & $0.4 \%$ \\
\hline 2015 & $9.4 \%$ & $17.8 \%$ & $3.1 \%$ & $16.5 \%$ & $11.2 \%$ & $4.0 \%$ & $6.8 \%$ & $3.7 \%$ & $8.0 \%$ & $6.8 \%$ & $7.3 \%$ & $0.1 \%$ & $4.8 \%$ & $0.3 \%$ \\
\hline
\end{tabular}


As has been mentioned above, there is long-term growth of the commodity aggregate 0 - Food and live animals. This is strongly influenced by the commodity sub-aggregates 02 - Dairy products and bird eggs, 04 - Cereals and cereal preparations. The proportion of these aggregates to the overall agrarian foreign trade of the post-Soviet countries has long-term retained the level exceeding 10\% for each monitored aggregate. Contrariwise, the commodity aggregates 00,41 and 43 are insignificant.

According to the division mentioned in Fig. 1 and Tab. 3, it can be concluded that in 2000 Russia possessed the largest number of commodity aggregates (9x), followed by Azerbaijan (7x), Ukraine (6x) and Belarus $(5 x)$. This quadrant also includes products that possess a comparative advantage (RCA $>1)$, while the countries are also competitive within their mutual trade relations (LFI > 0). 05 - Vegetables and fruit was the most frequently occurring commodity aggregate in this quadrant $(9 x)$, at a considerable margin followed by 12 - Tobacco and tobacco manufactures $(5 x)$ and 11 - Beverages a 07 - Coffee, tea, cocoa, spices, and manufactures thereof (both 4x).

Armenia, Kyrgyzstan or Tajikistan occupy the opposite positions, that is possess no evident comparative advantage and competitiveness for the majority of the monitored commodities. 12 out of 15 of the monitored commodity aggregates are placed in quadrant number III for all of these countries. Kazakhstan (11 aggregates), Georgia and Turkmenistan (10 commodity aggregates each) follow. In terms of commodity aggregates, $10 \times 04$ - Cereals and cereal preparations can be identified here, followed by 02 - Dairy products and bird eggs, 01 - Meat and meat preparations.

When drawing a comparison with 2015, a problem arises, namely that the data for Tajikistan and Turkmenistan are not available. The comparison will thus be performed excluding these two countries.

As in 2000, Russia records the largest number of comparative advantages connected with overall competitiveness of its production (Tab. 3). In total, 8 out of its monitored commodity aggregates are located in quadrant I. In comparison with 2000 , the number of commodity aggregates decreased by one. The position of some commodity aggregates also changed. 7 out of them did not record any change. With regard to Cereals and cereal preparations, the situation is reversed as the country lost its position within RCA and competitiveness, which is the result of the increasing proportion of animal production. A contrary situation occurred regarding Tobacco and tobacco manufactures, in which Russia improved its status and, in comparison with 2000 , it records both a competitive advantage and competitiveness in this commodity aggregate.

When assessing individual aggregates for the whole group of countries, the worst position is recorded in the case of Dairy products and bird eggs, Coffee, tea, cocoa, spices, and manufactures thereof, Tobacco and tobacco manufactures. This position could be expected regarding the last two, although it was rather unexpected in the case of dairy products, considering the fact that cow milk in particular is produced in all the monitored countries. The participation of the monitored countries in the global milk production exceeds $10.5 \%$. Russia, Ukraine, Uzbekistan and Belarus are among its most important producers. Concurrently, this commodity aggregate represents a significant proportion in the overall agrarian trade within the monitored countries.

However, except for cow milk, the monitored countries also produce goat, sheep, camel or buffalo milk. Regarding the last two, the production is merely minor and present in Georgia, Uzbekistan or Russia. On the contrary, goat or sheep milk is produced in the majority of the countries. Although this product is very important within agrarian markets, an evident comparative advantage is recorded only by Belarus, Ukraine and Kazakhstan. Simultaneously, coverage of import by export in the majority of the countries is negligible. In 2015, comparative advantages (RCA > 1) were gained only by Belarus. As regards Armenia, Kyrgyzstan and Moldova, intra-industry trade can be discussed, in which GLI is $>0.5$. When comparing 2000 and 2015, the position of the Russian Federation deteriorated sharply (Fig. 3). Its competitiveness decreased or its comparative advantages, intra-industry trade and coverage of import by export weakened. This decline is connected with the sanctions imposed against Russia by the European Union and other countries, since these profoundly affected trade in agricultural commodities (Kutlina-Dimitrova, 2017). 


\section{Tab. 3: Commodity groups according to division in Fig. 1}

\begin{tabular}{|c|c|c|c|c|c|c|c|c|}
\hline & \multicolumn{4}{|c|}{2000} & \multicolumn{4}{|c|}{2015} \\
\hline & $\begin{array}{c}\mathrm{I} . \\
\mathrm{RCA}>1 \\
\mathrm{LFI}>0\end{array}$ & $\begin{array}{c}\text { II. } \\
\text { RCA }<1 \\
\text { LFI }>0\end{array}$ & $\begin{array}{c}\text { III. } \\
\mathrm{RCA}<1 \\
\mathrm{LFI}<0\end{array}$ & $\begin{array}{c}\text { IV. } \\
\text { RCA }>1 \\
\text { LFI }<0\end{array}$ & $\begin{array}{c}\mathrm{I} . \\
\mathrm{RCA}>1 \\
\mathrm{LFI}>0\end{array}$ & $\begin{array}{c}\text { II. } \\
\text { RCA }<1 \\
\text { LFI }>0\end{array}$ & $\begin{array}{c}\text { III. } \\
\text { RCA }<1 \\
\text { LFI }<0\end{array}$ & $\begin{array}{c}\text { IV. } \\
\text { RCA }>1 \\
\text { LFI }<0\end{array}$ \\
\hline 00 & AR, RU, TR & TJ & $\begin{array}{l}\text { AR, AZ, GE, KZ, } \\
\mathrm{KG}, \mathrm{MO}, \mathrm{UA}\end{array}$ & UZ & $\begin{array}{l}\text { GE, KG, RU, } \\
\text { UA, UZ }\end{array}$ & BE & $A R, A Z, K Z$ & -- \\
\hline 01 & UA & $\mathrm{BE}, \mathrm{MO}$ & $\begin{array}{l}\text { AR, AZ, GE, KZ, } \\
\text { KG, RU, TJ, TR, } \\
\text { UZ }\end{array}$ & -- & BE, UA & MO & $\begin{array}{l}\text { AR, AZ, GE, KZ, } \\
K G, R U, U Z\end{array}$ & -- \\
\hline 02 & BE & $\mathrm{RU}, \mathrm{UA}$ & $\begin{array}{l}\text { AR, AZ, GE, KZ, } \\
\text { KG, RU, TJ, TR, } \\
\text { UA }\end{array}$ & -- & $B E, U A$ & $K G, U A$ & $\begin{array}{l}\text { AR, AZ, GE, KZ, } \\
M O, R U, U Z\end{array}$ & -- \\
\hline 03 & RU & TR & & $\mathrm{BE}$ & $A R, B E$ & GE & $\begin{array}{l}\mathrm{AZ}, \mathrm{KZ}, \mathrm{KG}, \mathrm{MO} \\
\mathrm{RU}, \mathrm{UA}, \mathrm{UZ}\end{array}$ & - \\
\hline 04 & KZ, RU & -- & $\begin{array}{l}\text { AR, AZ, BE, GE, } \\
\text { KG, MO, TJ, TR, } \\
\text { UA, UZ }\end{array}$ & -- & $\mathrm{KZ}, \mathrm{RU}$ & UA & $\begin{array}{l}\text { AR, AZ, BE, GE, } \\
K G, M O, U Z\end{array}$ & -- \\
\hline 05 & $\begin{array}{l}\text { AR, AZ, BE, } \\
\text { GE, KG, MO, } \\
\text { TJ, TR, UZ }\end{array}$ & $K Z$ & $R U, U A$ & -- & $\begin{array}{l}\text { AR, AZ, GE, } \\
\text { KG, MO, UZ }\end{array}$ & -- & $\mathrm{KZ}, \mathrm{RU}, \mathrm{UA}$ & BE \\
\hline 06 & BE, RU, UA & GE & $\begin{array}{l}\text { AR, AZ, KZ, KG, } \\
\text { MO, TJ, TR, UZ }\end{array}$ & -- & BE, UA & -- & $\begin{array}{l}\mathrm{AR}, \mathrm{AZ}, \mathrm{GE}, \mathrm{KZ}, \\
\mathrm{KG}, \mathrm{MO}, \mathrm{UZ}\end{array}$ & RU \\
\hline 07 & $\begin{array}{l}\text { AZ, GE, RU, } \\
\text { UA }\end{array}$ & $\mathrm{BE}$ & $\begin{array}{l}\text { AR, KZ, KG, MO, } \\
\text { TJ, TR, UZ }\end{array}$ & -- & RU & $A Z$ & $\begin{array}{l}\text { AR, BE, GE, KZ, } \\
\text { KG, MO, UZ }\end{array}$ & UA \\
\hline 08 & $A Z, R U, U Z$ & -- & $\begin{array}{l}\text { AR, BE, GE, KZ, } \\
\text { KG, MO, TJ, TR }\end{array}$ & UA & RU, UA & KZ & $\begin{array}{l}\text { AR, AZ, GE, KG, } \\
M O, U Z\end{array}$ & GE \\
\hline 09 & BE, RU & $A Z$ & $\begin{array}{l}\text { AR, GE, KZ, KG, } \\
\text { MO, TJ, TR, UA, } \\
\text { UZ }\end{array}$ & -- & $A Z, R U, U A$ & -- & $\begin{array}{l}\text { AR, BE, GE, KZ, } \\
\text { KG, MO, UZ }\end{array}$ & -- \\
\hline 11 & $\begin{array}{l}\text { AR, AZ, GE, } \\
\text { MO }\end{array}$ & UZ & $\begin{array}{l}\text { BE, KZ, KG, RU, } \\
\text { TJ, TR, UA }\end{array}$ & -- & AR, GE, MO & UZ & $\begin{array}{l}A Z, G E, K Z, K G \\
R U, U A\end{array}$ & -- \\
\hline 12 & $\begin{array}{l}\text { BE, KG, TJ, } \\
\text { UA, UZ }\end{array}$ & -- & AR, BE, RU, TR, & GE, MO & RU & UZ & $\begin{array}{l}\text { AZ, BE, GE, KZ, } \\
\text { KG. MO }\end{array}$ & $A R, U A$ \\
\hline 41 & MO, UA & -- & $\begin{array}{l}\text { BE, GE, KZ, KG, } \\
\text { RU, TJ }\end{array}$ & & BE, UA & GE, MO & $\begin{array}{l}A R, A Z, K Z, K G \\
R U, U Z\end{array}$ & -- \\
\hline 42 & $A Z, R U, U A$ & MO & $\begin{array}{l}\text { AR, BE, GE, KZ, } \\
\text { KG, TJ, TR, UZ }\end{array}$ & & $A Z, R U$ & UA & $\begin{array}{l}\text { AR, BE, GE, KZ, } \\
K G, M O, U Z\end{array}$ & -- \\
\hline 43 & $A Z, R U, T R$ & KG, UA & $\begin{array}{l}\text { AR, BE, GE, KZ, } \\
M O, T J, ~ U Z\end{array}$ & -- & $A Z, R U$ & -- & $\begin{array}{l}\text { AR, BE, GE, KZ, } \\
\mathrm{KG}, \mathrm{MO}, \mathrm{UZ}\end{array}$ & UA \\
\hline
\end{tabular}

Regarding Ukraine, its inter-industry trade slightly declined, although it was already relatively low. However, Ukraine decreased its own comparative advantage. In 2000, its RCA reached 0.879 , whereas in 2015 its value was as low as 0.391. Nevertheless, based on the statistical tests, a significant change in the competitiveness of the monitored countries 
in the commodity aggregate Dairy products cannot be confirmed.

When comparing the commodity aggregate Cereals and cereal preparations, it is Kazakhstan and Russia that record longterm competitiveness. Coverage of import by export in these countries is also extensive. Contrariwise, it is insignificant in the case of Azerbaijan, Kyrgyzstan, Moldova or Uzbekistan. Cereals play an important role in agricultural production of the post-Soviet republics. When comparing the overall segment of cereals, the production value of the post-Soviet republics represents $5.76 \%$ of the global production.

The contribution of Russia reaches $2.62 \%$ and of Ukraine $1.8 \%$. Should the focus be on wheat only, that is a commodity connected with food security, then the post-Soviet republics' contribution to the overall production amounts to $14.5 \%$, while the proportion of Russia and Ukraine exceeds $10 \%$ of the global production.

The commodity aggregate 11 - Beverages is the third most important component within agricultural trade. The Lafay index records long-term positive values in Armenia, Georgia, Moldova. These countries also record the highest value of the Balassa index, although their value of GLI is low, which signifies interindustry trade only. In the case of LFI and GLI, the correlation between these two values in negative. Uzbekistan is another competitive country, even though the value of the Lafay index fluctuates around 0.4 . The remaining countries' value of LFI and RCA is negative.

\section{Division of Products According to Their Characteristics}

A cluster analysis was used in order to assess the countries' position and individual commodity aggregates. The initial input variables were LFI, GLI, RCA, and coverage of import by export. The RCA index was excluded due to a high degree of correlation; other variables no longer demonstrate a statistically significant correlation. The cluster analysis was always conducted to compare years 2000 and 2015 .

Individual commodity aggregates were classified into categories based on these variables (Tab. 4 and Tab. 5). This concerns four to six categories, in which Ukraine possesses the largest number of categories in 2000 and Kyrgyzstan in 2015, which was influenced by significant differences between individual commodity aggregates.
In 2000, the commodity aggregates in Armenia were divided into 5 categories, whereas in 2015 into 4. As regards Armenia, the number of the commodities with a low level of all the monitored indicators increased. The position of Beverages and Cereals is considerably different in comparison with other aggregates. Regarding Cereals, the values of all the indicators are low, while Beverages record high levels of LFI and simultaneously a significant decline in coverage of import by export during the period of 2000-2015.

The cluster analysis divided the commodity groups of Azerbaijan into 4 categories in 2000 and 5 in 2015, two of which remained similar. These are the aggregates whose calculated indicators are continuously low on the one hand (group 1) and, on the other hand, there are aggregates with high LFI (group 3 -2015). These groups possess considerably different characteristics. Group 5 (2015) consists of Sugar and sugar preparations only and reaches a very high level of GLI and coverage of import by export. Regarding milk and cereals, Azerbaijan is uncompetitive and continuously records very low ratio of import to export.

While in 2000 Belarus' commodity structure was divided into 3 homogeneous categories, there was a dramatic change in 2015 in the position of Dairy products and Fish and crustaceans. The value of LFI and coverage of import by export for these two commodity aggregates greatly exceed the average of the group. As regards dairy products, however, the value of GLI remains low, which signifies lower value of intra-industry trade.

Georgia's classification is similar, where the number of categories increased from three to five between 2000 and 2015 when commodity aggregates Beverages and Tobacco became distinct. The value of the LFI index of the former is high, while the latter records extensive coverage of import by export. The structure of the category also changed, with a high rate of inter-industry trade. While in 2000 the values exceeded 0.9, in 2015 they decreased to around 0.6 and, simultaneously, the commodity aggregates which recorded these values changed. This therefore signifies that the country is beginning to focus more on interindustry trade in the given aggregates. This is particularly evident in group three, where the GLI value is well below average and the value of LFI is also low. The commodity aggregate 
Cereals also recorded a significant decrease with the GLI value decreasing from 0.39 to 0.09 . Concurrently, this aggregate records extensive coverage of import by export.

Cereals and cereal preparations represent a commodity aggregate with the highest value of calculated indicators in both monitored periods. This aggregate records a high value of LFI as well as the most extensive coverage of import by export. In comparison with 2000 , greater diversification between individual aggregates occurred in 2015, while the number of commodities with low values of GLI increased, which indicates non-existence of the intraindustry trade. However, this is not unusual in agrarian aggregates. Group 5 is interesting as it represents aggregates with a high value of LFI and $\mathrm{GLI}$ and also a low degree of coverage of import by export.

In terms of comparative advantages, live animals, vegetables and fruit and dairy products were the most important aggregates for Kyrgyzstan in 2015. Nevertheless, each of these exhibits different characteristics. The remaining groups are characterized, for instance, by negative LFI or average GLI - group 1, or by all the values below average - group 4.

Moldova's coverage of import is rather low for 10 commodity aggregates. On the contrary, meat and meat preparations occupy a very good position and also record high values of intra-industry trade. During the monitored period, the situation of vegetables and fruit improved. Contrariwise, beverages occupy a strong position and record extensive coverage of import by export throughout the entire monitored period. This is also the reason why this commodity aggregate is isolated.

The situation of Russia is fairly specific. The number of comparative advantages implies that the majority of the monitored commodity aggregates achieve a very good market position. One group consists of aggregates whose LFI and coverage of import exceeds the average. This concerns, for example, cereals and cereal preparations or feeding stuff for animals. Commodity aggregates Tobacco and Animal and vegetable fats are in a similar position. Values in group 4 greatly exceed the average. Group 2, containing dairy products only, appears problematic as all the indicators have been below average of the aggregates over the recent years. The impact of sanctions is clearly evident in this case.
When assessing the position of the Russian Federation only in terms of RCA and LFI, it can be stated that an improvement of the situation occurred in the commodity aggregates Fish (03), Coffee, tea, cocoa and spices (07) or Fixed vegetable fats and oils (42), There was no significant change in the position of the commodity aggregates Meat and meat preparations (01), Vegetables and fruit (05) and Beverages (11). These categories still do not attain competitiveness. The competitiveness of the commodity aggregate Dairy products and bird eggs (02) severely deteriorated. However, the position of Russia has long-term been specific. There is a regulation from 2010 , in which the Russian president approved the Food Security Doctrine of the Russian Federation. Russian Presidential Administration Doctrine of Food Security, Strategy of National Security of the Russian Federation till 2020. Nevertheless, simultaneously, sanctions were imposed against Russia in 2014 by the European Union and other countries that concern food and agricultural products. In response to the sanctions, on August 6, 2014, president Putin issued the Decree No. 560 "On Special Economic Measures to Protect Russia's Security".

Based on the above, it can be concluded that $\mathrm{HO}$ can be rejected. Competitiveness of the monitored countries in individual commodity aggregates is currently different.

Regarding Tajikistan and Turkmenistan, the comparison is impossible since the data for 2015 are not available. Both countries are competitive with respect to vegetables and fruit, whereas they record negative values of LFI in commodity aggregates $01,02,08$.

While in 2000 the commodity aggregates connected with Ukraine were divided into 6 groups, in 2015 there were only 4 . In 2000 , the structure of its foreign trade was slightly more diversified. Cereals and cereal preparations comprise a separate group which did not possess any comparative advantage, although the value of GLI exceeded the average of all the commodity aggregates. Also, fixed vegetable fats and oils recorded a high export - import ratio. The value of LFI for the commodity aggregate Meat and meat preparations exceeded 8.

Regarding Uzbekistan, the commodity aggregate Vegetables and fruit occupies a specific position. In both monitored years this 


\section{Tab. 4: Division of products according to their characteristics (2015)}

\begin{tabular}{|c|c|c|c|c|c|c|c|c|c|c|}
\hline \multirow{2}{*}{ 를 } & & 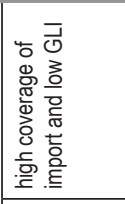 & 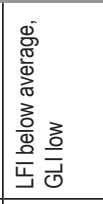 & 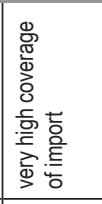 & 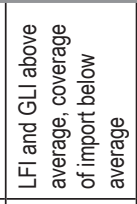 & 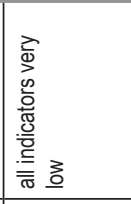 & 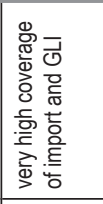 & 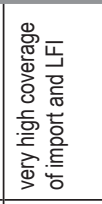 & & \\
\hline & & 8 & \begin{tabular}{|l}
$\bar{y}$ \\
$\delta$ \\
$o$ \\
0 \\
0 \\
0 \\
8 \\
\end{tabular} & $\simeq$ & 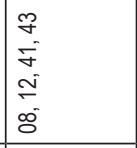 & d & $\delta$ & F & & \\
\hline \multirow[t]{2}{*}{$\begin{array}{l}\geq \\
\text { ō } \\
\text { 훈 }\end{array}$} & 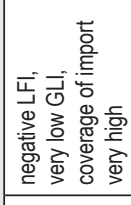 & 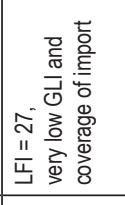 & 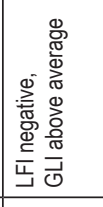 & 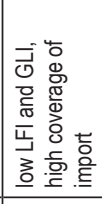 & 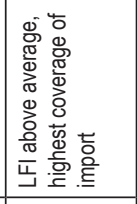 & 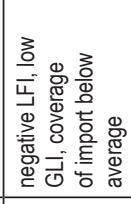 & : & 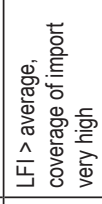 & 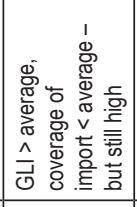 & 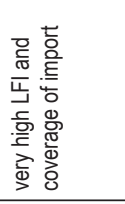 \\
\hline & $\begin{array}{l}8 \\
8 \\
\end{array}$ & 18 & $\begin{array}{l}8 \\
80 \\
80 \\
0=\end{array}$ & $\begin{array}{l}\mathcal{Z} \\
\mathcal{O}\end{array}$ & $\begin{array}{l}\text { षे } \\
\text { cे }\end{array}$ & 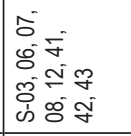 & $\stackrel{\mathscr{F}}{=}$ & $\begin{array}{l}\mathscr{P} \\
\stackrel{2}{\sim}\end{array}$ & 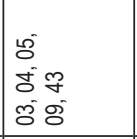 & 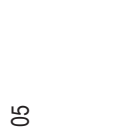 \\
\hline \multirow[t]{2}{*}{ 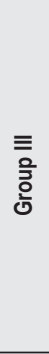 } & 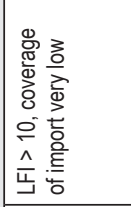 & 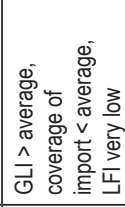 & 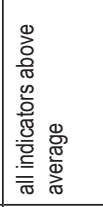 & 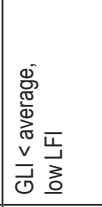 & 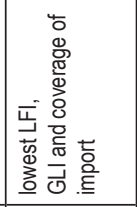 & 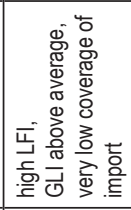 & 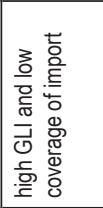 & 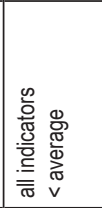 & 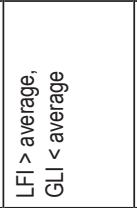 & 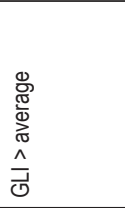 \\
\hline & $\begin{array}{l}= \\
\text { हs }\end{array}$ & 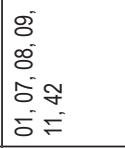 & $\varnothing$ & 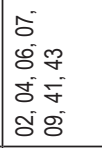 & 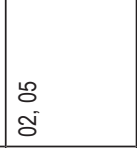 & ชิ & $\begin{array}{l}2 \\
0 \\
\tilde{8}\end{array}$ & $\widetilde{\sigma}$ & 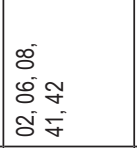 & $\begin{array}{l}8 \\
5 \\
0 \\
8\end{array}$ \\
\hline \multirow[t]{2}{*}{$\begin{array}{l}\overline{\overline{0}} \\
\text { 은 }\end{array}$} & 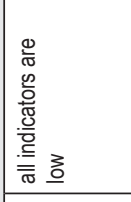 & 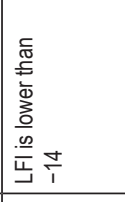 & 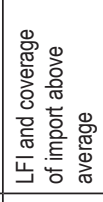 & 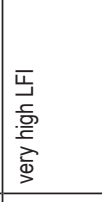 & 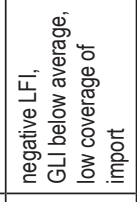 & 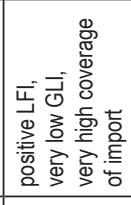 & 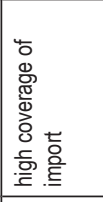 & 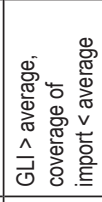 & 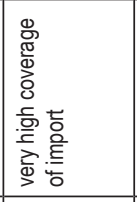 & 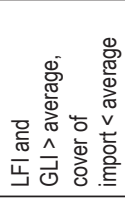 \\
\hline & 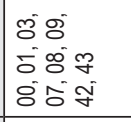 & $\begin{array}{l}\cong \\
0\end{array}$ & $\widetilde{\sigma}$ & $F$ & $\begin{array}{l}507 \\
50 \\
5 \\
5\end{array}$ & $\overline{0}$ & $\frac{\sim}{8}$ & $\begin{array}{l}8= \\
58 \\
80 \\
80\end{array}$ & $\begin{array}{l}\bar{\delta} \\
\bar{\delta}\end{array}$ & 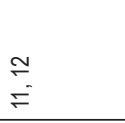 \\
\hline \multirow[t]{2}{*}{$\begin{array}{l}\overline{0} \\
\text { 은 }\end{array}$} & 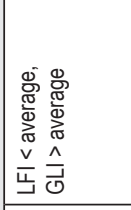 & 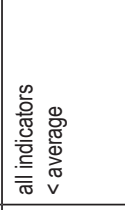 & 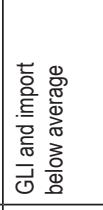 & 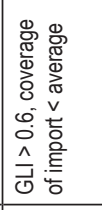 & 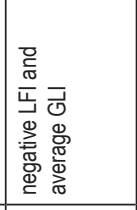 & 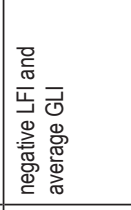 & 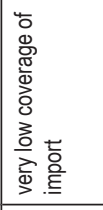 & 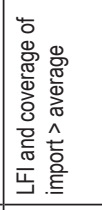 & 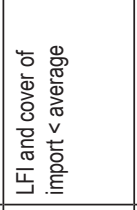 & 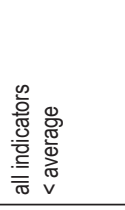 \\
\hline & $\begin{array}{l}\bar{\sigma} \\
\\
\tilde{\sigma} \\
\tilde{\sigma}\end{array}$ & 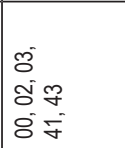 & 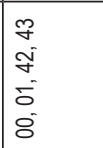 & $\begin{array}{l}8 \\
8 \\
50 \\
80 \\
8\end{array}$ & $\begin{array}{l}= \\
8 \\
8 \\
8 \\
8 \\
8\end{array}$ & $\begin{array}{l}= \\
8 \\
8 \\
8\end{array}$ & 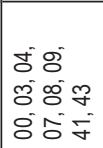 & 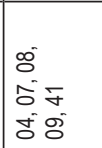 & 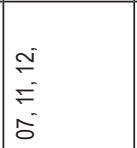 & 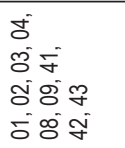 \\
\hline ڤ̊. & 孚 & Q & 岗 & 崩 & $\underline{x}$ & Oִ & $\stackrel{\circ}{2}$ & 고 & I & $\stackrel{N}{د}$ \\
\hline
\end{tabular}




\section{Tab. 5: Division of products according to their characteristics (2000)}

\begin{tabular}{|c|c|c|c|c|c|c|c|c|c|c|c|c|}
\hline \multirow[t]{2}{*}{$\begin{array}{l}\text { 을 } \\
\text { 혼 }\end{array}$} & 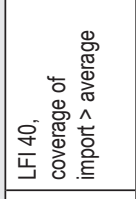 & & & & & 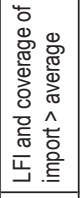 & 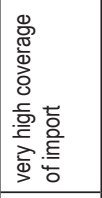 & $\begin{array}{l}\infty \\
0 \\
0 \\
11 \\
4 \\
\end{array}$ & 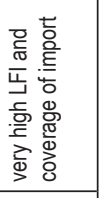 & & 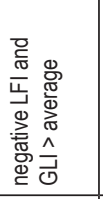 & 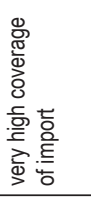 \\
\hline & $=$ & & & & & $\frac{2}{8}$ & $\mp$ & 농 & 농 & & ¿ & $\stackrel{8}{8}$ \\
\hline \multirow[t]{2}{*}{$\begin{array}{l}\geq \\
\text { 혼 } \\
\text { 인 }\end{array}$} & $\begin{array}{l}\bar{J} \\
\text { 要 } \\
\text { 兽 } \\
\end{array}$ & 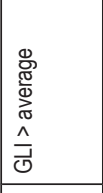 & & 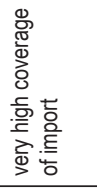 & 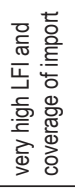 & 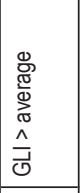 & 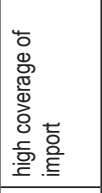 & 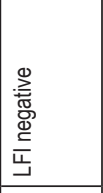 & 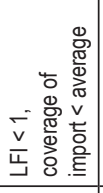 & 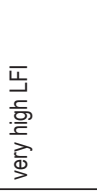 & 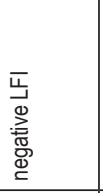 & 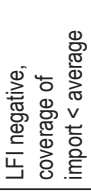 \\
\hline & $\simeq$ & 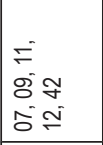 & & $E$ & ¿ & $\begin{array}{l}\text { m } \\
9 \\
8 \\
0 \\
0 \\
8 \\
8\end{array}$ & $\delta$ & $\begin{array}{l}\bar{y} \\
\simeq \\
\Xi \\
E \\
5\end{array}$ & $\begin{array}{l}\text { \% } \\
8 \\
8\end{array}$ & $\stackrel{8}{\circ}$ & $\begin{array}{l}20 \\
8 \\
8 \\
8 \\
8\end{array}$ & $\begin{array}{l}9 \\
9 \\
5 \\
8 \\
8\end{array}$ \\
\hline \multirow[t]{2}{*}{$\begin{array}{l}\equiv \\
\overline{3} \\
\text { 원 }\end{array}$} & 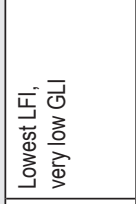 & 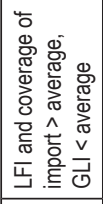 & 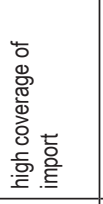 & 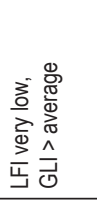 & 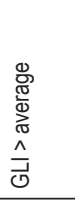 & $\begin{array}{l}\infty \\
1 \\
11 \\
\underline{\Xi} \\
\end{array}$ & 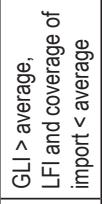 & 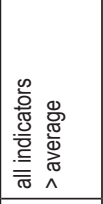 & 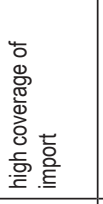 & 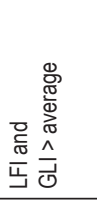 & 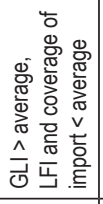 & 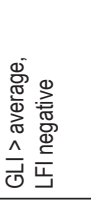 \\
\hline & ष & $\begin{array}{l}\text { कु } \\
\text { o } \\
\text { s. } \\
8\end{array}$ & $\begin{array}{l}8 \\
8 \\
8 \\
\dot{0} \\
8 \\
8\end{array}$ & ष & $\begin{array}{l}= \\
8 \\
8 \\
8 \\
8 \\
8\end{array}$ & \& & 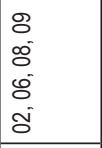 & $\begin{array}{l}8 \\
\text { o- }\end{array}$ & $\simeq$ & $\begin{array}{l}\tilde{8} \\
\text { r } \\
\end{array}$ & $\begin{array}{l}E \\
8 \\
0^{\circ} \\
0^{\circ}\end{array}$ & 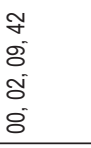 \\
\hline \multirow[t]{2}{*}{$\begin{array}{l}\overline{\overline{2}} \\
\text { 은 }\end{array}$} & 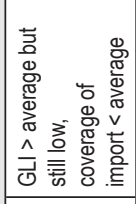 & 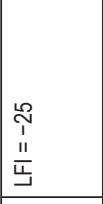 & 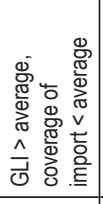 & 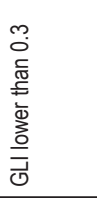 & 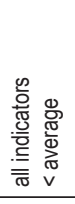 & 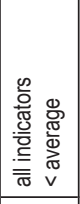 & 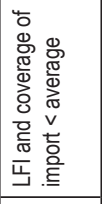 & 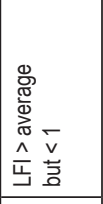 & 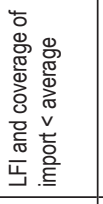 & 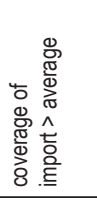 & 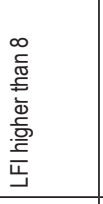 & 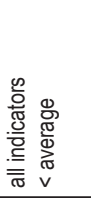 \\
\hline & 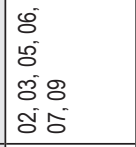 & ¿ & $\begin{array}{l}5 \\
8 \\
8 \\
5 \\
0 \\
8\end{array}$ & 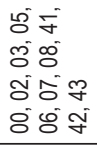 & $\begin{array}{l}\tilde{\sigma} \\
\delta\end{array}$ & $\begin{array}{l}y \\
y \\
\bar{y} \\
0 \\
5 \\
5\end{array}$ & 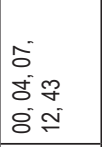 & \begin{tabular}{|l} 
m \\
o \\
0 \\
8 \\
\end{tabular} & $\begin{array}{l}= \\
8 \\
5 \\
5\end{array}$ & 8 & $\delta$ & ¿ \\
\hline \multirow[t]{2}{*}{$\begin{array}{l}\overline{\frac{a}{3}} \\
\text { 인 }\end{array}$} & 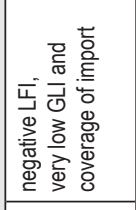 & 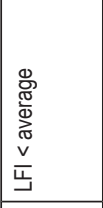 & 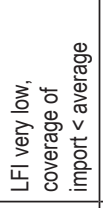 & 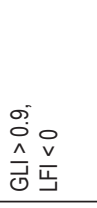 & 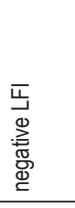 & 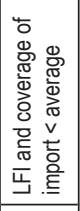 & 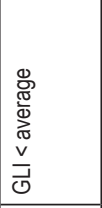 & 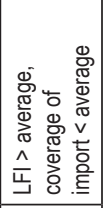 & 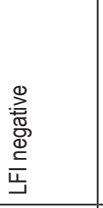 & $\begin{array}{l}\text { ㅁ } \\
\frac{u}{\exists}\end{array}$ & 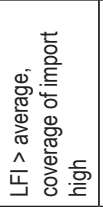 & 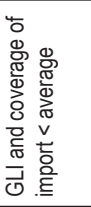 \\
\hline & 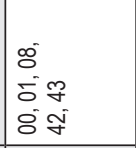 & 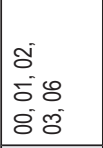 & 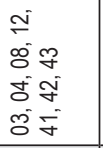 & $\begin{array}{l}\simeq \\
8 \\
5 \\
5\end{array}$ & 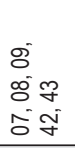 & $\begin{array}{l}\text { E } \\
8 \\
0 \\
0 \\
0 \\
5\end{array}$ & \begin{tabular}{l}
7 \\
\multirow{y}{y}{} \\
8 \\
8 \\
8
\end{tabular} & 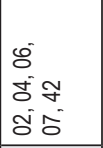 & 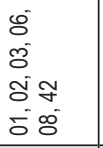 & 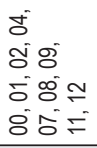 & 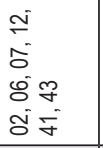 & 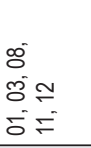 \\
\hline ర్రి & 妥 & Z & 岗 & 岕 & 포 & प्र & $\stackrel{\circ}{2}$ & $\vec{\partial}$ & 尸 & $\stackrel{\complement}{\mathscr{1}}$ & 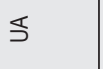 & $\stackrel{N}{د}$ \\
\hline
\end{tabular}

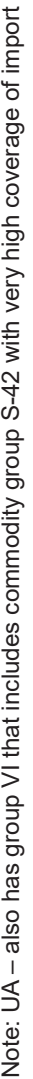


aggregate records a high value of coverage of import and LFI. Whereas in 2000 Uzbekistan's structure was more diversified, a significant change occurred in 2015 when all indicators for 9 commodity aggregates reach values below average of individual indicators. It might be stated that only few aggregates improve their positions.

Based on the results of the cluster analysis (Tab. 4 and Tab. 5), it can be concluded that $\mathrm{H} 1$ does not reflect the reality since there are significant changes within the structure of the groups consisting of the monitored commodity aggregates.

When only a comparative advantage or a competitive advantage of the monitored commodity aggregates is considered (in the matrix of 10 countries $\times 15$ aggregates), it might be stated that, in comparison with 2000 , the position of 6 aggregates improved in 2015 as these were placed in the 1st quadrant.

On the contrary, a deterioration in the position is evident in 15 aggregates (a combination of aggregate $x$ country) which were excluded from the 1st quadrant. The 3rd quadrant contains the largest number of countries with no comparative advantage and no competitiveness. Unless Turkmenistan and Tajikistan are considered, deterioration in the position occurred in 10 aggregates.

The monitored countries continuously record the highest values of comparative advantages and competitiveness in group 05 - Vegetables and fruit. In four of these (RU, TJ, TR, UZ), these aggregates comprised a separate group in 2000, whereas in 2015 this concerned mere 2 countries ( $A Z, U Z)$.

\section{Tab. 6: Hypothesis test summary - comparison of commodity group}

\begin{tabular}{l|c|c|c|c|c|c|c|c|c|c|c|c|c|c|c} 
Com. & 00 & $\mathbf{0 1}$ & $\mathbf{0 2}$ & $\mathbf{0 3}$ & $\mathbf{0 4}$ & $\mathbf{0 5}$ & $\mathbf{0 6}$ & $\mathbf{0 7}$ & $\mathbf{0 8}$ & $\mathbf{0 9}$ & $\mathbf{1 1}$ & $\mathbf{1 2}$ & $\mathbf{4 1}$ & $\mathbf{4 2}$ & $\mathbf{S} 43$ \\
\hline RCA & 0.51 & 0.26 & 0.65 & 0.86 & 0.01 & 0.01 & 0.29 & 0.96 & 0.72 & 0.58 & 0.14 & 0.29 & 0.35 & 0.86 & 0.88 \\
\hline LFI & 0.06 & 0.31 & 0.27 & 0.10 & 0.07 & 0.03 & 0.81 & 0.58 & 0.94 & 0.75 & 0.31 & 0.70 & 0.96 & 0.88 & 0.16 \\
\hline
\end{tabular}

Note: Asymp. Sig. (2-tailed), the significance level is 0.05

A comparison of the values of RCA and LFI in the period of 2000-2015 indicates that the null hypothesis can be rejected (Tab. 6) only in two cases concerning RCA - the commodity aggregate 04 - Cereals and cereal preparations and 05 - Vegetables and fruit, and in one case concerning LFI (again, Vegetables and fruit); the median value of the difference between two variables equals 0 . In the remaining cases, the value exceeds 0.05 , therefore the null hypothesis cannot be rejected. It is thus impossible to reject hypothesis $H 1$. It might therefore be stated that there is no significant difference in the competitiveness between the monitored years for the given commodity aggregates with the exception mentioned above.

\section{Discussion}

When comparing years 2000 and 2015, a higher degree of individual countries' interconnectedness is evident, mainly of those linked to Russia. This has been observed by Myant and Drahokoupil (2008). Concurrently, the structure of individual countries' foreign trade gradually changes. Closer connectedness between individual geographical units is evident. Contrary to 2000 , there has been a significant shift in trade towards EU by Georgia, for instance, rather than towards Russia and other post-Soviet republics (Jenish, 2013). In terms of economic openness, it could be stated that Tajikistan and Uzbekistan rank among the countries closest to autarchy in 2015. Similar conclusions have also been drawn by Bose (2005), Cameron et al. (2012) and Korosteleva (2016) who add that the export structure of these countries is also problematic.

It seems that the post-Soviet countries are losing their competitive advantage although, for example, Russia is still exporting large volumes of its production. However, this trend can have 
a negative impact on the entire economic situation in the future not only in the Russian Federation, but in all the post-Soviet republics. Its basic manifestation is overall deterioration of competitiveness, which will be manifested in the decline of terms of trade. Similar conclusions, reflected in the overall deterioration of the economic situation, have been supported by (Idrisov, Ponomarev, \& Sinelnikov-Murylev, 2016) as well. Simultaneously, depending on the production focus and the degree of processing it is evident that, with the higher degree of aggregation, agricultural products along with natural raw materials comprise nearly $46 \%$ of the overall trade. There is a concurrent increase in the proportion of agricultural products. The trend is connected with the improving selfsufficiency of the Russian Federation in food production. However, it can be manifested again in the deterioration of economic prospects or, as (Belke, Dreger, \& Dubova, 2019) remonstrate, in an impaired reaction to economic shocks.

Although in the case of the majority of the commodity aggregates Russia represents a country which possesses a comparative and competitive advantage, its position is fairly weak regarding Vegetables and fruit. The value of LFI in 2000 is the lowest in all the monitored countries and the second lowest in 2015. The value of RCA is also nearly the lowest in the monitored period.

Dairy products significantly contribute to the agrarian foreign trade of the post-Soviet countries. Russia and Kazakhstan are among the key players, although none of them occupy a clear position consisting of LFI and RCA values. However, in the case of Russia, these represented an important export commodity before the introduction of the sanctions (Erokhin, Heijman, \& Ivolga, 2014). At the same time, it was a well-protected sector of Russian agricultural trade in the past (Wegren, 2005). As regards LFI, a significant decline in the position in 2015 is evident, which is influenced by the economic sanctions and by the increase of home production consumption. In the period before imposing the sanctions, the value of LFI was the third highest in the group of the monitored countries, after Belarus and Ukraine. This position was affected by high profitability of Russian dairy industry (Špička \& Kontsevaya, 2016).

Since this matter is still topical, there has not been a sufficient theoretical base which could be proceeded. Similarly, it is not possible to really utilize the examples of the sanctions already imposed on other countries (Erokhin, 2015; Haidar, 2017), since this concerns a strong economic player with significant international transactions. The economic relationship of Russia with the former Soviet Union countries is a significant factor related to the possible impact of the sanctions on the Russian Federation. At the beginning of the monitored period and before the start of the war, the Ukrainian position was improving, which corresponds with the conclusions drawn by (Qineti, Rajcaniova, \& Matejkova, 2009). (Fal'tsman, 2014; Pokrivcak, van Berkum, Drgova, Mraz, \& Ciaian, 2013) have discovered that, apart from the EU countries, the former post-Soviet countries were the most important business partners for Russia. These countries represent a potential source of income for Russia and mutually form an interconnected trading bloc. (Khorana \& Martínez-Zarzoso, 2019) state that if the states trade within the existing regional bloc, their trade is $3 x$ greater than in other countries.

\section{Conclusions}

Agrarian foreign trade represents an important source of income for the monitored countries. The commodity aggregate 0 - Food and live animals (one-digit) records a continuously growing trend. The development of the proportion of other aggregates is permanent without any significant changes. When categorizing into a two-digit code, the commodity aggregate 02 - Dairy products and eggs contributes to export at the greatest extent. During the monitored period, an increase by 6 percentage points occurred, also 04 - Cereals and cereal preparations (with a 4-percentage point increase). Contrariwise, 06 - Sugar, sugar preparations and honey and 11 - Beverages recorded a decrease.

RCA and LFI indexes were used in order to evaluate the position of the countries on international markets. A comparative advantage and competitiveness of these countries was evaluated using these indexes. As regards RCA, the position of the commodity aggregate 04 - Cereals and cereal preparations and 05 - Vegetables and fruit changed between 2000 and 2015. No changes were recorded in regard to the remaining aggregates. By applying the test to LFI a change in the 
commodity aggregate 05 - Vegetables and fruit was confirmed. These aggregates recorded a change in competitiveness. No changes were confirmed in the remaining aggregates. Despite these partial changes, based on the conducted tests, it is not possible to clearly reject the hypothesis connected with the changes in the competitiveness of the majority of the monitored commodity aggregates.

Based on the division of individual commodity aggregates into quadrants that define their position within competitiveness and comparative advantage when comparing years 2000 and 2015, it can be concluded that there are significant differences between the monitored countries. Russia is the country with the largest number of variables included in the 1st quadrant, which represented the most competitive products, with 9 or 8 aggregates in the monitored years. Armenia, Kyrgyzstan or Tajikistan are on the opposite side. It is thus possible to reject $\mathrm{HO}$ that the competitiveness of the monitored countries in individual commodity aggregates is currently similar.

The cluster analysis enabled division of individual commodity aggregates for the monitored countries into groups based on the values of GLI, LFI and coverage of import/export. Subsequently, these groups of commodity aggregates were characterized for individual countries. Based on the conducted analyses, it might be stated that $\mathrm{H} 1$ about the non-existence of significant changes within the group structure does not reflect the reality. Between 2000 and 2015, there were considerable changes in the division of commodity aggregates into groups formed according to their common characteristics as part of foreign trade.

The diversity of the foreign trade between 2000 and 2015 also decreased as more commodity aggregates attain values around or below average of a particular aggregate. Regarding the intra-industry trade, it could be stated that some commodity aggregates could be regarded as important in relation to the post-Soviet countries' market only in the case of Azerbaijan, Russia, Belarus, Kazakhstan and Ukraine. This phenomenon occurs most frequently in the commodity aggregates Beverages or Vegetables and fruit.

Acknowledgement: This paper was supported by the Grant Agency at the Faculty of
Economics and Management, Czech University of Life Sciences Prague: Economic specifics of the post-Soviet countries [no. 20181018] and by Ministry of Agriculture NAZV Duality in the Czech Agriculture [QK1920398].

\section{References}

Azizov, U. (2017). Regional integration in Central Asia: From knowing-that to knowinghow. Journal of Eurasian Studies, 8(2), 123-135. https://doi.org/10.1016/j.euras.2017.02.002

Balassa, B. (1965). Trade Liberalisation and Revealed Comparative Advantage. The Manchester School, 33(2), 99-123. https://doi. org/10.1111/j.1467-9957.1965.tb00050.x

Balassa, B. (1977). 'Revealed' Comparative Advantage Revisited: An Analysis of Relative Export Shares of the Industrial Countries, 1953-1971. The Manchester School, 45(4), 327-344. https://doi.org/10.1111/j.1467-9957. 1977.tb00701.x

Belke, A., Dreger, C., \& Dubova, I. (2019). On the exposure of the BRIC countries to global economic shocks. World Economy, 42(1), 122-142. https://doi.org/10.1111/twec.12674

Benešová, I., Maitah, M., Smutka, L., Tomšík, K., \& Ishchukova, N. (2017). Perspectives of the Russian agricultural exports in terms of comparative advantage. Agricultural Economics (Czech Republic), 63(7), 318-330. https://doi. org/10.17221/344/2015-AGRICECON

Benešová, I., Novotná, Z., Šánová, P., \& Laputková, A. (2016a). Agriculture of the postSoviet countries. In L. Smutka (Ed.), Agrarian Perspectives XXV. Global and European Challenges for Food Production, Agribusiness and the Rural Economy, Proceedings of the 25th International Scientific Conference, 14-16 September 2016, Prague, Czech Republic (pp. 41-50). Prague: Czech University of Life Sciences Prague.

Benešová, I., Novotná, Z., Šánová, P., \& Laputková, A. (2016b). Economic Comparison of Agricultural Sector of Eurasian Countries - Is There Any Potential for Development Through Economic Cooperation? AGRIS On-Line Papers in Economics and Informatics, 8(2), 19-31. https://doi.org/10.7160/aol.2016.080202

Benešová, I., Smutka, L., \& Laputková, A. (2019). Specifics of the Mutual Trade of the Post-Soviet Countries. Enterpreneurial Business and Economic Review, 7(1), 29-43. https://doi.org/10.15678/EBER.2019.070102 
Bildirici, M. E., \& Kayikçi, F. (2013). Effects of oil production on economic growth in Eurasian countries: Panel ARDL approach. Energy, 49, 156-161. https://doi.org/10.1016/j. energy.2012.10.047

Bose, N. (2005). Endogenous growth and the emergence of equity finance. Journal of Development Economics, 77(1), 173-188. https://doi.org/10.1016/j.jdeveco.2004.03.005

Buja, A., \& Swayne, D. F. (2002). Visualization Methodology for Multidimensional Scaling. Journal of Classification, 19(1), 7-43. https://doi.org/10.1007/s00357-001-0031-0

Cameron, D. R. et al. (2012). Post-Soviet Authoritarianism: The Influence of Russia in Its "Near Abroad". Post-Soviet Affairs, 28(1), 1-44. https://doi.org/10.2747/1060-586X.28.1.1

Cavalcanti, T. V. de V., Mohaddes, K., \& Raissi, M. (2011). Growth, development and natural resources: New evidence using a heterogeneous panel analysis. The Quarterly Review of Economics and Finance, 51(4), 305318. https://doi.org/10.1016/j.qref.2011.07.007

Cavoli, T. (2012). Exploring dimensions of regional economic integration in East Asia: More than the sum of its parts? Journal of Asian Economics, 23(6), 643-653. https://doi. org/10.1016/j.asieco.2012.07.001

Chiaruttini, M. S. (2014). EU, Russia and the Reshaping of the Post-Soviet Space: An International Trade Analysis. Paper presented at the 54th Congress of the European Regional Science Association: "Regional development \& globalisation: Best practices", 26-29 August 2014, St. Petersburg, Russia.

Commendatore, P., Kubin, I., Petraglia, C., \& Sushko, I. (2014). Regional integration, international liberalisation and the dynamics of industrial agglomeration. Journal of Economic Dynamics and Control, 48, 265-287. https://doi.org/10.1016/j.jedc.2014.07.011

Cormier, K. E. (2007). Grievance practices in post-Soviet Kyrgyz agriculture. Law and Social Inquiry, 32(2), 435-466. https://doi. org/10.1111/j.1747-4469.2007.00065.x

Erokhin, V. (2015). Contemporary Reshaping of Eurasian Integration: Russia's Policies and their Implication for the EU and EurAsEC. Procedia Economics and Finance, 22, 402-411. https://doi.org/10.1016/S2212-5671(15)00313-5

Erokhin, V., Diao, L., \& Du, P. (2020). Sustainability-Related Implications of Competitive Advantages in Agricultural Value Chains: Evidence from Central Asia - China
Trade and Investment. Sustainability, 12(3), 1117-1145. https://doi.org/10.3390/su12031117

Erokhin, V., Heijman, W., \& Ivolga, A. (2014). Trade Tensions Between EU and Russia: Possible Effects on Trade in Agricultural Commodities for Visegrad Countries. Visegrad Journal on Bioeconomy and Sustainable Development, 3(2), 52-57. https://doi. org/10.2478/vjbsd-2014-0010

Espinoza, R., Prasad, A., \& Williams, O. (2011). Regional financial integration in the GCC. Emerging Markets Review, 12(4), 354-370. https://doi.org/10.1016/j.ememar.2011.04.005

Fal'tsman, V. K. (2014). Evaluation of the competitiveness of Russian products in world, CIS, EAEC, and non-CIS markets. Studies on Russian Economic Development, 25(1), 69-76. https://doi.org/10.1134/S1075700714010055

Garanina, O. (2009). What beyond oil and gas? Russian trade specialisation in manufactures. Post-Communist Economies, 21(1), 1-29. https://doi.org/10.1080/14631370802663596

Garanina, O., \& Pankki, S. (2008). What beyond oil and gas? Russian trade specialisation in manufactures (BOFIT Discussion Paper No. 23/2008). Helsinky: Bank of Finland.

Geldi, H. K. (2012). Trade effects of regional integration: A panel cointegration analysis. Economic Modelling, 29(5), 1566-1570. https://doi.org/10.1016/j.econmod.2012.05.017

Gnidchenko, A. A., \& Salnikov, V. A. (2013). Dynamics of Russia's Competitive Positions on Foreign Markets. Studies on Russian Economic Development, 24(6), 555-569. https://doi. org/10.1134/S1075700713060051

Gnidchenko, A., \& Sal'nikov, V. (2014). Price Competitiveness in Russian Foreign Trade. Problems of Economic Transition, 57(5), 3-36. https://doi.org/10.2753/PET1061-1991570501

Grubel, H. G., \& Lloyd, P. J. (1971). The Empirical Measurement of Intra-Industry Trade. Economic Record, 47(4), 494-517. https://doi. org/10.1111/j.1475-4932.1971.tb00772.x

Guesmi, K., \& Teulon, F. (2014). The determinants of regional stock market integration in middle east: A conditional ICAPM approach. International Economics, 137, 2231. https://doi.org/10.1016/j.inteco.2013.10.006

Haidar, J. I. (2017). Sanctions and export deflection: evidence from Iran. Economic Policy, 32(90), 319-355. https://doi.org/10.1093/ epolic/eix002

Hale, H. E. (2010). Eurasian polities as hybrid regimes: The case of Putin's Russia. 
Journal of Eurasian Studies, 1(1), 33-41. https://doi.org/10.1016/j.euras.2009.11.001

Hale, H. E. (2011). The Myth of Mass Russian Support for Autocracy: The Public Opinion Foundations of a Hybrid Regime. Europe-Asia Studies, 63(8), 1357-1375. https://doi.org/10.1080/09668136.2011.601106

Hare, P., Estrin, S., Lugachyov, M., \& Takla, L. (1998). Russia's Foreign Trade: New Directions and Western Policies. The World Economy, 21(1), 95-119. https://doi. org/10.1111/1467-9701.00121

Havránek, T., Horváth, R., \& Zeynalov, A. (2016). Natural Resources and Economic Growth: A Meta-Analysis. World Development, 88, 134-151. https://doi.org/10.1016/j. worlddev.2016.07.016

Horváth, R., \& Zeynalov, A. (2014). The natural resource curse in post-soviet countries: The role of institutions and trade policies (IOS Working Paper No. 341). Regensburg: Institut für Ost- und Südosteuropaforschung. Retrieved from http://nbn-resolving.de/ urn:nbn:de:101:1-2014070810451

lapadre, P. L. (2001). Measuring international specialization. International Advances in Economic Research, 7(2), 173-183. https://doi.org/10.1007/BF02296007

Idrisov, G., Ponomarev, Y., \& SinelnikovMurylev, S. (2016). Terms of trade and Russian economic development. Russian Journal of Economics, 2(3), 279-301. https://doi. org/10.1016/J.RUJE.2016.09.002

Jenish, N. (2013). Regional Trade and Economic Growth in the CIS Region (Working Paper No. 13). Bishkek: Institute of Public Policy and Administration.

$\mathrm{Ke}, \mathrm{S}$. (2015). Domestic market integration and regional economic growth - China's recent experience from 1995-2011. World Development, 66, 588-597. https://doi. org/10.1016/j.worlddev.2014.09.024

Khorana, S., \& Martínez-Zarzoso, I. (2019). Twenty-First-Century Trade Governance: Findings From the Commonwealth Countries. Contemporary Economic Policy, 38(2), 380-396. https://doi.org/10.1111/coep.12450

Korosteleva, E. A. (2016). The European Union and Belarus: Democracy promotion by technocratic means? Democratization, 23(4), 678-698. https://doi.org/10.1080/13510347.20 15.1005009

Kumar, S., Sen, R., \& Srivastava, S. (2014). Does economic integration stimulate capital mobility?? An analysis of four regional economic communities in Africa. Journal of International Financial Markets, Institutions and Money, 29, 33-50. https://doi.org/10.1016/j. intfin.2013.11.001

Kutlina-Dimitrova, Z. (2017). The economic impact of the Russian import ban: a CGE analysis. International Economics and Economic Policy, 14(4), 537-552. https://doi. org/10.1007/s10368-017-0376-4

Lafay, J. (1992). The Measurement of Revealed Comparative Advantages. In M. G. Dagenais \& P. A. Muet (Eds.), International Trade Modeling (pp. 209-234). London: Chapman and Hall.

Laursen, K. (2015). Revealed comparative advantage and the alternatives as measures of international specialization. Eurasian Business Review, 5(1), 99-115. https://doi.org/10.1007/ s40821-015-0017-1

Lerman, Z. (2009). Land reform, farm structure, and agricultural performance in CIS countries. China Economic Review, 20(2), 316-326. https://doi.org/10.1016/j. chieco.2008.10.007

Libman, A. (2007). Regionalisation and regionalisminthe post-Sovietspace:Currentstatus and implications for institutional development. Europe-Asia Studies, 59(3), 401-430. https://doi. org/10.1080/09668130701239849

Libman, A., \& Vinokurov, E. (2018). Autocracies and regional integration: the Eurasian case. Post-Communist Economies, 30(3), 334-364. https://doi.org/10.1080/14631 377.2018.1442057

Linn, J. (2012). Central Asian Regional Integration and Cooperation: Reality or Mirage? In EDB Eurasian Integration Yearbook 2012 (1st ed., pp. 96-117). Almaty: Eurasian Development Bank.

Malle, S. (2012). The Policy Challenges of Russia's Post-Crisis Economy. PostSoviet Affairs, 28(1), 66-110. https://doi. org/10.2747/1060-586X.28.1.66

Mazhikeyev, A., \& Edwards, T. H. (2013). Central Asian Trade Relations in the PostSoviet Era (Discussion Paper Series 2013_02). Loughborough: Loughborough University. Retrieved from http://www.etsg.org/ETSG2013/ Papers/126.pdf

Mazhikeyev, A., Edwards, T. H., \& Rizov, M. (2015). Openness and isolation: The trade performance of the former Soviet Central Asian countries. International Business Review, 
24(6), 935-947. https://doi.org/10.1016/j. ibusrev.2015.03.001

Minniti, A., \& Parello, C. P. (2011). Trade integration and regional disparity in a model of scale-invariant growth. Regional Science and Urban Economics, 41(1), 20-31. https://doi. org/10.1016/j.regsciurbeco.2010.07.003

Myant, M., \& Drahokoupil, J. (2008). International Integration and the Structure of Exports in Central Asian Republics. Eurasian Geography and Economics, 49(5), 604-622. https://doi.org/10.2747/1539-7216.49.5.604

Obydenkova, A., \& Libman, A. (2016). Autocratic and Democratic External Influences in Post-Soviet Eurasia. London: Taylor and Francis.

Pokrivcak, J., van Berkum, S., Drgova, L., Mraz, M., \& Ciaian, P. (2013). The role of nontariff measures in EU dairy trade with Russia. Post-Communist Economies, 25(2), 175-189. https://doi.org/10.1080/14631377.2013.787737

Portanskii, A. (2012). Russia and the World Trade Organization. Problems of Economic Transition, 55(1), 63-77. https://doi. org/10.2753/PET1061-1991550106

Qineti, A., Rajcaniova, M., \& Matejkova, E. (2009). The competitiveness and comparative advantage of the Slovak and the EU agri-food trade with Russia and Ukraine. Agricultural Economics (Czech Republic), 55(8), 375-383. https://doi.org/10.17221/42/2009-AGRICECON

Rosner, B., Glynn, R. J., \& Lee, M.-L. T. (2006). The Wilcoxon Signed Rank Test for Paired Comparisons of Clustered Data. Biometrics, 62(1), 185-192. https://doi. org/10.1111/j.1541-0420.2005.00389.x

Rueda-Junquera, F. (1998). Regional integration and agricultural trade in Central America. World Development, 26(2), 345-362. https://doi.org/10.1016/S0305-750X(97)10038-9
Salnikov, V. A., Gnidchenko, A. A., \& Galimov, D. I. (2016). Industry-level effects from integration between Russia, Belarus and Kazakhstan through industrial cooperation. Studies on Russian Economic Development, 27(1), 101-113. https://doi.org/10.1134/ S1075700716010123

Spechler, M. C., \& Spechler, D. R. (2013). Russia's lost position in Central Eurasia. Journal of Eurasian Studies, 4(1), 1-7. https://doi.org/10.1016/j.euras.2012.08.001

Špička, J., \& Kontsevaya, S. R. (2016). Differences of Financial Management Strategy of Central European and Russian Milk Processors. AGRIS On-Line Papers in Economics and Informatics, 8(1), 89-102. https://doi.org/10.7160/aol.2016.080109

Torgerson, W. S. (1952). Multidimensional scaling: I. Theory and method. Psychometrika, 17(4), 401-419. https://doi.org/10.1007/ BF02288916

Ward, J. H. J. (1963). Hierarchical Grouping to Optimize an Objective Function. Journal of American Statistical Association, 58(301), 236244. https://doi.org/10.1080/01621459.1963.10 500845

Weber, G. (2003). Russia's and Kazakhstan's agro-food sectors under liberalized agricultural trade: a case for national product differentiation. Economic Systems, 27(4), 391-413. https://doi. org/10.1016/j.ecosys.2003.11.002

Wegren, S. K. (2005). Russian Agriculture during Putin's First Term and Beyond. Eurasian Geography and Economics, 46(3), 224-244. https://doi.org/10.2747/1538-7216.46.3.224

Yun, Y., \& Park, K. (2012). An Analysis of the Multilateral Cooperation and Competition between Russia and China in the Shanghai Cooperation Organization: Issues and Prospects. Pacific Focus, 27(1), 62-85. https://doi.org/10.1111/j.1976-5118.2012.01076.x 